\title{
Analysis Accounting Treatment of Generic Medicine Inventories Based on PSAP 052010 at Dr.H.Moh.Anwar Sumenep Regency
}

\author{
Djoko Nestri K*, Aprilya Dwi Yandari \\ Departement Accounting of Economics and Business, Wiraraja University, Madura Islands -Indonesian \\ *Corresponding Author: Djoko Nestri K, Departement Accounting of Economics and Business, \\ Wiraraja University, Madura Islands -Indonesian
}

\begin{abstract}
The process of detecting and determining the amount of generic drugs to always be available at the Dr. H. Moh. Anwar Regional Hospital can be done when supported by the recording and assessment process carried out by someone who has the competence to do so based on existing guidelines. This research method is a comparative qualitative method with a qualitative approach. The data collection technique used in this study was to use the interview method and documentation study to obtain data and information about generic drug stock-taking cards and generic FIFO supply cards for dr. H. Moh. Anwar Hospital, Sumenep Regency. The recording of generic drug supplies should be done based on a perpetual method as stipulated in PSAP No. 05/2010 which has not been fully implemented in RSUD Dr. H. Moh. Anwar, Sumenep Regency. So based on research conducted by researchers, it is advisable for the hospital to implement inventory recording in accordance with PSAP No. 05/2010. In addition, it is also recommended for the hospital to improve its control system because the data requested by researchers are not available. So that there is also a need for accuracy and a proper assessment of drug supplies that needs to be done so that later if there is a shortage or absence of drug supplies it will have a fatal impact on both the patient and the hospital.
\end{abstract}

Keywords: Inventory, PSAP No.05/2010, FIFO, FEFO

\section{INTRODUCTION}

One form of hospital success is carrying out duties and service responsibilities as seen from the success of a doctor in diagnosing complaints or illnesses of his patients, accuracy in administering drug doses to patients is one of the supporting factors for the success of the service system and patient recovery. This is in line if drug or pharmaceutical support devices can become an important element of the main service in the hospital. Based on this, it is an important and inseparable part of hospital services, because it is a form of orientation to patient care, the provision of quality drugs, as well as a clinical pharmacy service that is easily accessible to the public. The use of medicine for hospitals is an important element, because the role of the hospital is to provide good service, cure and prevent disease for the community. So that medicine is a support for the healing and prevention of a disease by patients who are undergoing treatment. If there is an empty stock of drugs when needed, it can cause losses for many parties. One of them is in the patient element, where the patient cannot get treatment on time. This will later affect the patient's worsening which can result in the loss of a patient's life. In addition, it can also cause a decrease in the credibility of hospital services for patients or the general public. Another thing, if it is viewed from the elements of the hospital, if the hospital does not have a drug stock or drug supply it will have an impact on profit loss. Loss of profit can occur if the patient or the public will turn to services at other hospitals that are quite alert and able to provide good and complete services. Therefore, the empty stock of drugs can be or if the availability of drugs is less on time, there will be a decrease in the value of the volume of patient visits which affects the minimum hospital cash receipts and the lack of hospital performance. This can happen in all hospitals, including the regional hospital in Sumenep Regency, namely Dr. H. Moh. Anwar Hospital.

RSUD dr. H. Moh. Anwar to provide good service in terms of outpatient and inpatient care requires drugs that are always available. One of them is the type of generic drug, both generic injection and generic in tablet form which is often used. This often has the potential to run out of stock if one drug is needed in a cyto way. If the availability of drugs in cyto conditions is a solution for the pharmacy by contacting the doctor concerned to confirm if the drug needed by the patient is not available. Then the doctor can later replace the drug needed with almost the same drug. However, if the replaced drugs also run out of stock, the pharmacy will purchase drugs outside the hospital pharmacy. Where 
these factors later there can be a delay in the service system that is immediately provided so that it will affect the patient who will be increasingly sick or even lose the life of a patient. Then this can be demonstrated by the need for a process to determine the amount of generic drugs needed. The process of detecting and determining the amount of generic drugs to always be available at the Dr. H. Moh. Anwar Regional Hospital can be done when supported by the recording and assessment process carried out by someone who has the competence to do so based on existing guidelines. Therefore, it is urgently needed a research on the analysis of the supply of generic drugs in RSUD Dr. H. Moh. Anwar Sumenep in accordance with PSAP No. 05/2010.

\section{LITERATURE REVIEW}

\subsection{The Role of Accounting in Hospitals}

Based on operations in management accounting for hospitals, hospitals are required to provide data, information, and instructions in order to be able to encourage hospital leaders when carrying out the planning, controlling, and monitoring processes for all activities so that the quality of service can be maintained or improved at the level of a good and reasonable financing. Lubis (2014: 3) expressed his opinion that "In general, hospital accounting can be defined as an information system that produces reports to parties who have an interest in hospital economic activities". Based on Lubis' explanation, it shows that the implementation of accounting in the hospital is able to produce information that is used by managers to carry out hospital activities, including in determining the need for generic drugs for patient care.

\subsection{Inventory}

Libby (2007: 336) argues that Inventory is a tangible asset of a company to be sold in normal business operations or for use in obtaining a product and service that will be sold later. Inventories are reported on the balance sheet as current assets, because inventories are generally used to turn into cash with a maturity of 1 year or when the operating cycle is in the following year. The type of inventory itself depends on a characteristic of the business. This has been listed in the Governmental Accounting Standards Statement (PSAP) No. 05 paragraph 05 (2010: 05); Inventories are assets in the form of:

a. Goods or supplies used during government operational processes.

b. Materials or supplies that will be used during the production process.

c. Goods in the production process that are described as being sold or given to the public,

d. Items that are stored for sale or given to the public during government activities.

\subsubsection{Inventory Recording System}

The process of recording inventory items is an important thing that companies do in recording the cost of goods, for example on products to be sold or when the goods are used during daily government operations. In the inventory recording technique based on Martani, (2012: 250): when recording inventory, technical inventory recording is related to the recording system used by the entity. Where entities use a periodic or perpetual system. Periodic system is the process of recording the quantity of inventory which is determined periodically with only one physical calculation which is carried out by means of stock taking. Meanwhile, the perpetual system is the process of recording an up-to-date inventory of an inventory that is carried out when the inventory value changes.

James (2009: 348), the inventory cost method and the perpetual inventory system is a perpetual system where the entire increase and decrease when the inventory is recorded using the same method as the process of recording the increase or decrease in cash. The inventory account at the beginning of the period shows that the inventory yield was at that date. Purchases are recorded by debiting inventories and crediting cash or trade payables. So that at the date of sale, the cost of goods sold is recorded by debiting the cost of goods sold and crediting inventory. Referring to the opinion of these scientists, it is concluded that inventories can be recorded using a perpetual method and a periodic method. Inventory recording using a perpetual system is carried out every time an incoming and outgoing goods transaction occurs and at the end of the period a physical count is carried out, while inventory recording using the periodic method only records inventory at the end of the period by performing a physical count of goods without recording the goods in and out. 


\subsubsection{Inventory Valuation Method}

Based on a theory that an entity uses a special price related to goods that have been determined at the cost of supplies. However, in fact it is difficult to do because the entity carries out a large purchase transaction and the goods are mass products (mass production) which are difficult to specifically identify and are able to mutually substitute each other. Accordingly, an entity uses the cost flow assumption in measuring the cost of inventory. Inventory valuation method according to Libby (2009: 224): In one period, an entity usually makes several purchases at different times and most likely the prices are different. If there are multiple purchases at a cost per unit of inventory, then there are four different methods that are allowed to be used, namely special identification, First In First Out (FIFO), Last In First Out (LIFO), and weighted average.

\subsubsection{Governmental Accounting Standard Statement No. 05 About Inventory.}

Governmental Accounting Standard Statement (PSAP) No. 05 of 2010 concerning inventory is a guideline or reference in a government entity to regulate the inventory process effectively and efficiently. The following is an explanation of the Governmental Accounting Standards Statement (PSAP) No. 05 of 2010 concerning supplies.

Scope of the Governmental Accounting Standard Statement No. 05/2010 (2018: 163): The Standard Statement is applied to the inventory presentation of financial statements which is adjusted based on its general purpose. These standards are applied to central and local government entities that are not categorized as state / regional companies. This Standard Statement does not address:

a. Inventories of raw materials and equipment owned by self-managed projects and charged to a construction account in progress, and

b. Financial instruments.

\section{RESEARCH METHODS}

This research method is a comparative qualitative method with a qualitative approach. Which in this study focuses on the process of recording and assessing the supply of generic drugs which use the most and often run out of stock, it requires some understanding of the inventory (according to the highest demand available at the hospital). The inventory recording process is carried out using a perpetual method, which is to record any changes in additions, expenses, and balances of five types of injection generic drugs and five generic tablets. The inventory appraisal process is a method used by Dr. H. Moh. Anwar Hospital in assessing injection generic drugs and tablets. Therefore, the inventory valuation is carried out using the FIFO or First In First Out method, which is an assessment process based on the assumption of the price of the inventory that has been sold or used by being assessed based on the purchase price of the goods that were previously entered, so that the final inventory is valued according to the purchase price of the last incoming item. The data collection technique used in this study was to use the interview method and documentation study to obtain data and information about generic drug stock-taking cards and generic FIFO supply cards for dr. H. Moh. Anwar Hospital, Sumenep Regency. The analytical method used in this research is to use comparative descriptive analysis. The analysis used was by comparing the recording and valuation of inventory using generic drug samples conducted by RSUD Dr. H. Moh. Anwar, Sumenep Regency using PSAP No. 05 of 2010 regarding inventories. The process of analysis stages used is as follows, including recording inventory using a perpetual method, namely the First In First Out (FIFO) valuation method.

\section{Results}

In all generic drugs recorded by dr. H. Moh. Anwar Hospital, Sumenep Regency on the drug stocktaking card using the model conducted by the researcher. So, based on the recording of generic tablets of amplodipin 5, amoxcilin 500, cefixime 100, clopidogrel 75mg, and amitriptyline, this was done in the same way. Where the results of recording and valuing supplies for the five types of generic tablets are based on the provisions of PSAP No. 05/2010, where the following results are obtained at the end of 2019:

Table1. Results of Ending Inventory 
Analysis Accounting Treatment of Generic Medicine Inventories Based on PSAP 052010 at Dr.H.Moh.Anwar Sumenep Regency

\begin{tabular}{|l|l|}
\hline \multirow{2}{*}{ AMLODIPIN 5 } & Rp. $13,470,750$ \\
\hline AMOXCILIN 500 & Rp. $1,685,730$ \\
\hline CEFIXIME 100 & Rp. $18,282,704$ \\
\hline CLOPIDOGREL 75MG & Rp. $13,017,888$ \\
\hline AMITRIPTILIN & Rp. 688,207 \\
\hline
\end{tabular}

Source: self-processed data (2020)

Based on the method of recording and valuing inventory based on PSAP No. 05/2010, which records inventory using the perpetual method and inventory valuation using the FIFO method, where at Dr. H. Moh. Anwar Hospital, Sumenep Regency, records and evaluates inventory by conducting comparison as in the table below:

Table2. Comparison According to PSAP No. 05/2010 with dr. H. Moh. Anwar Kab. Sumenep

\begin{tabular}{|l|l|l|l|}
\hline Description & $\begin{array}{l}\text { According to PSAP } \\
\text { No.05/2020 }\end{array}$ & $\begin{array}{l}\text { According to RSUD dr. } \\
\text { H. Moh. Anwar Sumenep }\end{array}$ & $\begin{array}{l}\text { Remarks (Match / Not } \\
\text { Match with Difference) }\end{array}$ \\
\hline Inventory Recording & Perpetual & Physical & Not appropriate \\
\hline Inventory Valuation & FIFO & FEFO & Not appropriate \\
\hline $\begin{array}{l}\text { Ending Inventory of } \\
\text { Generic Medicine }\end{array}$ & & & Price Gap \\
\hline AMLODIPIN 5 & Rp. 2.046.750 & Rp. 13.470.750 & Rp. 11,424,000 \\
\hline AMOXCILIN 500 & Rp. 134,700 & Rp. 1,685,730 & Rp. 1,551,030 \\
\hline CEFIXIME 100 & Rp. 5.178.000 & Rp. 18,282,704 & Rp. 13,104,704 \\
\hline CLOPIDOGREL 75 MG & Rp. 13,507,900 & Rp. 13,017,888 & Rp. (490,012) \\
\hline AMITRIPTILIN & - & Rp. 688,207 & Rp. 688,207 \\
\hline
\end{tabular}

Source: self-processed data (2020)

\subsection{Results}

Based on the recording of generic drug supplies, which should have been carried out based on a perpetual method as stipulated in PSAP No. 05/2010, it has not been fully implemented in Dr. H. Moh. Anwar Regional Hospital, Sumenep Regency. Recording that is carried out by the hospital is based on the recording of generic drug supplies, namely the physical recording method based on the drug stock card and physical counting at the end of the period, where there is no recording such as journaling which is carried out perpetually or periodically recording journaling. Where the resulting research based on these findings can prove that the hypothesis in recording generic drug supplies at RSUD Dr. H. Moh. Anwar Sumenep Regency is not in accordance with the Government Accounting Standard Statement (PSAP) No. 05/2010.

The assessment of generic drug supplies according to PSAP No. 05/2010 uses the FIFO method, while at the Dr. H. Moh. Anwar Regional Hospital, Sumenep Regency uses the FEFO or First Expired First Out method. Based on this, the result is a difference in the valuation of generic drugs inventory, where there will be differences in the assessment of the final inventory of generic drugs as seen in table 7. The difference will cause a difference in inventory value including Amplodipin 5 of Rp. $11,424,000$ (recorded that the number was greater at RSUD Dr. H. Moh. Anwar, Sumenep Regency). Furthermore, the difference in the value of AMOXCILIN 500's ending inventory of Rp. 1,551,030, where these results were recorded as being greater in RSUD Dr. H. Moh. Anwar, Sumenep Regency. Likewise, there was also a difference in the value of the ending inventory on generic tablets CEFIXIME 100 of Rp. 13. 104,704, where the recorded difference is greater by RSUD Dr. H. Moh. Anwar. In addition, there was also a negative difference in the ending inventory value where the generic drug CLOPIDOGREL $75 \mathrm{Mg}$ was Rp. 490,012 which was recorded as larger according to PSAP No. 05/2010. While the recording on the generic drug AMITRIPTILIN had a difference of Rp. 688,207 which was recorded as greater by dr. H. Moh. Anwar Hospital, Sumenep Regency.

Based on the explanation above, the assessment of the generic drug supply at dr. H. Moh. Anwar Hospital, Sumenep Regency is not in accordance with PSAP No. 05/2010. .H. Moh. Anwar Sumenep Regency has not used the FIFO method but uses the FEFO (First Expired First Out) method. So from the research results, there is no written evidence related to the assessment of generic drug supplies using the weighted average method, but only from the results of interviews with employees of the pharmacy depot at RSUD Dr. H. Moh Anwar, Sumenep Regency, stated that the inventory assessment 
was carried out. for the pharmaceutical depot using the weighted average method. In addition, if it is seen based on the system implemented by the dr. H. Moh. Anwar Regional Hospital using the FEFO method in assessing the supply of medicines, however, RSUD Dr. H. Moh. Anwar, Sumenep Regency cannot do the calculation of the drug supply assessment. according to the entry and exit of transactions, but only calculates the FEFO of transactions in each month. So that the results of the above research find that the findings support the research hypothesis.

If we look at the results of the difference in inventory value which is categorized into two categories, namely the excess difference category and the less difference then based on both of them will have a detrimental impact. If reviewed at dr. H. Moh. Anwar Regional Hospital, Sumenep regency generic drug Amplodipin 5, Amoxcilin 500, Cefixime 100, Clopidogrel 75Mg, and Amtriptilin which are considered quite large and it is recognized that there are still quite a lot of generic drugs available, Clopidogrel $75 \mathrm{Mg}$, which is considered to be in stock. viewed based on perpetual records and FIFO valuation is zero rupiah. Where this is of course the reason for the lack of inconvenience in medical services later in the Dr. H. Moh. Anwar Regional Hospital because generic drugs are considered to be widely available which when left unchecked will continue. Therefore, if one day the drugs will run out but we don't know yet, then there will be an impact on delayed patient care and will cause quite a danger to the Cito service system. So it will be the other way around, which later the generic drug Amplodipin 5 which is considered insufficient while it is available in quite a large number. Therefore, based on this explanation, it will have a detrimental impact because the drug can expire and there will be a very large capital expenditure which will only be used for drugs.

\section{CONCLUSION}

The recording of generic drug supplies should be done based on a perpetual method as stipulated in PSAP No. 05/2010 which has not been fully implemented in RSUD dr. H. Moh. Anwar, Sumenep Regency. Recording that is carried out by the hospital is based on the recording of generic drug supplies, namely the physical recording method based on the drug stock card and physical counting at the end of the period, where there is no recording such as journaling which is carried out perpetually or periodically recording journaling. Where the resulting research based on these findings can prove that the hypothesis in recording generic drug supplies at RSUD Dr. H. Moh. Anwar Sumenep Regency is not in accordance with the Government Accounting Standard Statement (PSAP) No. 05/2010.

Based on research conducted by researchers, it is advisable for the hospital to implement inventory recording in accordance with PSAP No. 05/2010. In addition, it is also recommended for the hospital to improve its control system because the data requested by many researchers are not available. So it also needs an accuracy and an assessment of drug supplies that need to be done so that later if there is a shortage or absence of drug supplies, it will have a fatal impact on both the patient and the hospital.

\section{REFERENCES}

[1] Diana, Anastasia., Setiawati, Lilis. 2017. Akuntansi Keuangan Menengah Berdasarkan Akuntansi Keuangan Terbaru. Yogyakarta: CV. Andi Offset

[2] Libby, Robert, Patricia A. Libby, Daniel G. Short. 2007. Akuntansi keuangan. Yogyakarta: Andi

[3] Lubis, Arfan Ikhsan dan Ida Bagus Agung Dharmanegara. 2014. Akuntansi dan Manajemen Keuangan Rumah Sakit. Yogyakarta: Graha Ilmu.

[4] Martani, Dwi. et, al. 2012. Akuntansi Keuangan Menengah Berbasis

[5] Nirwana. R, Elfreda. A.L, Kulsum, Ummi. 2019. Analisis Akuntansi Untuk Persediaan Obat Generik Berdasarkan Pada PSAP No.05 di RSUD Abdoel Wahab Sjahranie Samarinda. Research Journal of Accounting and Business Management (RJABM). Vol.3 No.1 : 80-96

[6] Reeve, James M. et, al. 2009. Principles of Accounting-Indonesia Adaptation. Jakarta: Salemba Empat.

Citation: Djoko Nestri K, Aprilya Dwi Yandari. “ Analysis Accounting Treatment of Generic Medicine Inventories Based on PSAP 052010 at Dr.H.Moh.Anwar Sumenep Regency " International Journal of Managerial Studies and Research (IJMSR), vol 8, no. 10, 2020, pp. 12-16. doi: https://doi.org/10.20431/23490349.0810002.

Copyright: (C) 2020 Authors. This is an open-access article distributed under the terms of the Creative Commons Attribution License, which permits unrestricted use, distribution, and reproduction in any medium, provided the original author and source are credited. 